Proceedings

\title{
Orchard floor weed cover does not influence infestation of peach trees by the peachtree borer, Synanthedon exitiosa ${ }^{\dagger}$
}

\author{
Daniel L. Frank ${ }^{1, *}$ and Rakesh S. Chandran ${ }^{2}$
}

Citation: Frank, D. L.; Chandran, R

S. Orchard floor weed cover does not influence infestation of peach trees by the peachtee borer, Synanthedon exitiosa, in Proceedings of the 1st International Electronic Conference on Entomology, 1-15 July 2021, MDPI: Basel, Switzerland, doi:10.3390/IECE-10408

Published: 30 June 2021

Publisher's Note: MDPI stays neutral with regard to jurisdictional claims in published maps and institutional affiliations.

Copyright: (C) 2021 by the authors. Submitted for possible open access publication under the terms and conditions of the Creative Commons Attribution (CC BY) license (http://creativecommons.org/licenses /by/4.0/).
1 Department of Entomology, College of Agriculture and Life Sciences, Virginia Tech, Blacksburg, VA, USA; dlfrank@vt.edu

2 Extension Service, Agriculture and Natural Resources Unit, West Virginia University, Morgantown, WV USA; RSChandran@mail.wvu.edu

* Correspondence: dlfrank@vt.edu

† Presented at the 1st International Electronic Conference on Entomology (IECE 2021), 1-15 July 2021; Available online: https://iece.sciforum.net/.

\begin{abstract}
The peachtree borer, Synanthedon exitiosa, is an economically important wood boring pest of peach and other stone fruit trees throughout much of the United States. Infestation and damage by larvae of this species is generally confined to the trunk and roots near the soil line. A two-year field experiment was conducted in a commercial peach orchard to study the effect of orchard floor weed cover on incidence of peachtree borer infestation in peach blocks under two different pest management regimes; mating disruption and conventional insecticides. During the study, weed cover did not significantly affect the mean percentage of peach trees infested by peach tree borer, regardless of management regime. A weak to small, negative Pearson correlation coefficient existed between weed cover ratings and the percentage of infested trees. Our hypothesis that weed free (bare soil) areas around the trunks of peach trees would favor peachtree borer infestation was not supported by our data.
\end{abstract}

Keywords: IPM; orchard understory; Sesiidae

\section{Introduction}

Management of orchard floor weeds is an important component of peach (Prunus persica [L.] Batsch) production systems. Weeds compete with trees for water and nutrients, provide habitat and/or alternative hosts for various pest organisms (i.e. insects, plant disease pathogens, rodents), and increase the risk of mechanical injury to the base of trees from mowing [1]. Although unmanaged weed growth is not a recommended crop production practice, weeds have been shown to play a productive role in some agroecosystems by negatively affecting insect pest populations [2-4]. Furthermore, weeds may also serve as a physical barrier to prevent certain insect pests from entering into, or emerging from the soil to complete their life cycle [5].

The peachtree borer, Synanthedon exitiosa (Say) (Lepidoptera: Sesiidae), is an economically important wood boring pest of stone fruit trees, particularly peach, throughout much of the United States. Host damage is generally confined to the trunk and roots near the soil line where developing larvae feed on the vascular cambium. Despite the amount of time present near the orchard floor, the response of peachtree borer to understory groundcover is unknown. The purpose of this study was to evaluate the effect of orchard floor weed cover on incidence of peachtree borer infestation in commercial peach plantings under two different pest management regimes; mating disruption and conventional insecticides. Because a weed free orchard understory provides few resources for natural enemies and unrestricted access to the base of trees, we hypothesized that weed free (bare soil) areas around the trunk of peach trees would favor peachtree borer infestation. 


\section{Materials and Methods}

\subsection{Study Site}

This study was conducted in a commercial peach orchard located in Hampshire County, WV in 2016 and 2017. Within the orchard, peach trees (2,885 total) were planted in six separate blocks, which were divided into two groups based on management programs for peachtree borer. Three blocks were managed using mating disruption, which involved uniform deployment of Isomate PTB-Dual disruption dispensers (50:50 ratio of (E,Z):(Z,Z)-3,13 ODDA; CBC America, Commack, NY, USA) in tree canopies. Dispensers were applied at a rate of 371/ha (150/A) in late April of each year before adult peachtree borer emergence. The other three blocks were managed using a post-harvest handgun application of chlorpyrifos insecticide $(2.8 \mathrm{~L} / 378.5 \mathrm{~L}$ dilution) directed to the lower scaffold limbs and trunks of trees. Weeds within the tree row of all blocks were managed using a combination of pre- and post-emergence herbicides applied with a short tractor mounted boom sprayer.

Previous research has shown that complete control of peachtree borer and perennial weeds in orchards are difficult to achieve $[1,6]$. Although the orchard in our study was under active arthropod and weed management programs, monitoring data collected before and during the study showed that populations of both pests were present in the orchard. During the study, the mean number of trees in the orchard with active peachtree borer infestations was 150 and 145 in 2016 and 2017, respectively. Similarly, the mean number of trees with some level of perennial weed cover in the surrounding tree row was 851 and 876 in 2016 and 2017, respectively.

\subsection{Insect and Weed Assessments}

Infestation of peach trees by peachtree borer larvae was evaluated at the end of each season in 2016 and 2017. Every tree was inspected within each block and the number of active feeding sites were recorded. An active feeding site was considered to be a discrete and contiguous area of fresh frass and gummosis at the base of trees. Weed coverage in tree rows was visually estimated in a $1 \mathrm{~m}^{2}$ sampling area surrounding the base of each tree at the same time as peachtree borer infestation assessments. Weed coverage was categorized at four different levels of infestation, as follows: $0=$ no weed coverage, $1=1-33 \%$ weed coverage, $2=34-66 \%$ weed coverage, and $3=67-100 \%$ coverage.

\subsection{DataAnalysis}

For each block, the number of infested trees in each weed coverage category were converted to proportion infested by dividing the number of infested trees by the total number of trees. Proportion data were analyzed using PROC GLIMMIX (SAS 9.2, SAS Institute, Cary, NC, USA) with a binomial distribution. The model contained the fixed effects of year, management program (i.e. mating disruption or insecticide), weed coverage, and all possible interactions. Replication (by block) was included as the random variable. Pearson correlation coefficient (PROC CORR; SAS 9.2, SAS Institute, Cary, NC, USA) was used to examine the correlation between the proportion of infested trees and weed coverage. Results from all tests were considered statistically different at $p<0.05$.

\section{Results}

The proportion of infested trees in orchard blocks did not vary significantly among year $(F=0.07 ; \mathrm{df}=1,30 ; p=0.7899)$, management program $(F=0.14 ; \mathrm{df}=1,30 ; p=0.7101)$, weed coverage $(F=0.03 ; \mathrm{df}=3,30 ; p=0.9926)$, the interaction of year $\mathrm{x}$ management program $(F=0.02 ; \mathrm{df}=1,30 ; p=0.8965)$, year $\mathrm{x}$ weed coverage $(F=0.01 ; \mathrm{df}=3,30 ; p=0.9986)$, management program $\mathrm{x}$ weed coverage $(F=0.01 ; \mathrm{df}=3,30 ; p=0.9997)$, or year $\mathrm{x}$ management program $\mathrm{x}$ weed coverage $(F=0.03 ; \mathrm{df}=3,30 ; p=0.9928)$. Therefore, the proportion of infested trees in each weed coverage category were pooled by year and management program and presented in Fig 1. A weak to small, negative correlation was found between 
the proportion of infested trees and weed coverage, which was not significant $(r=-0.1301$; $p=0.3781 ; \mathrm{n}=48$ ).

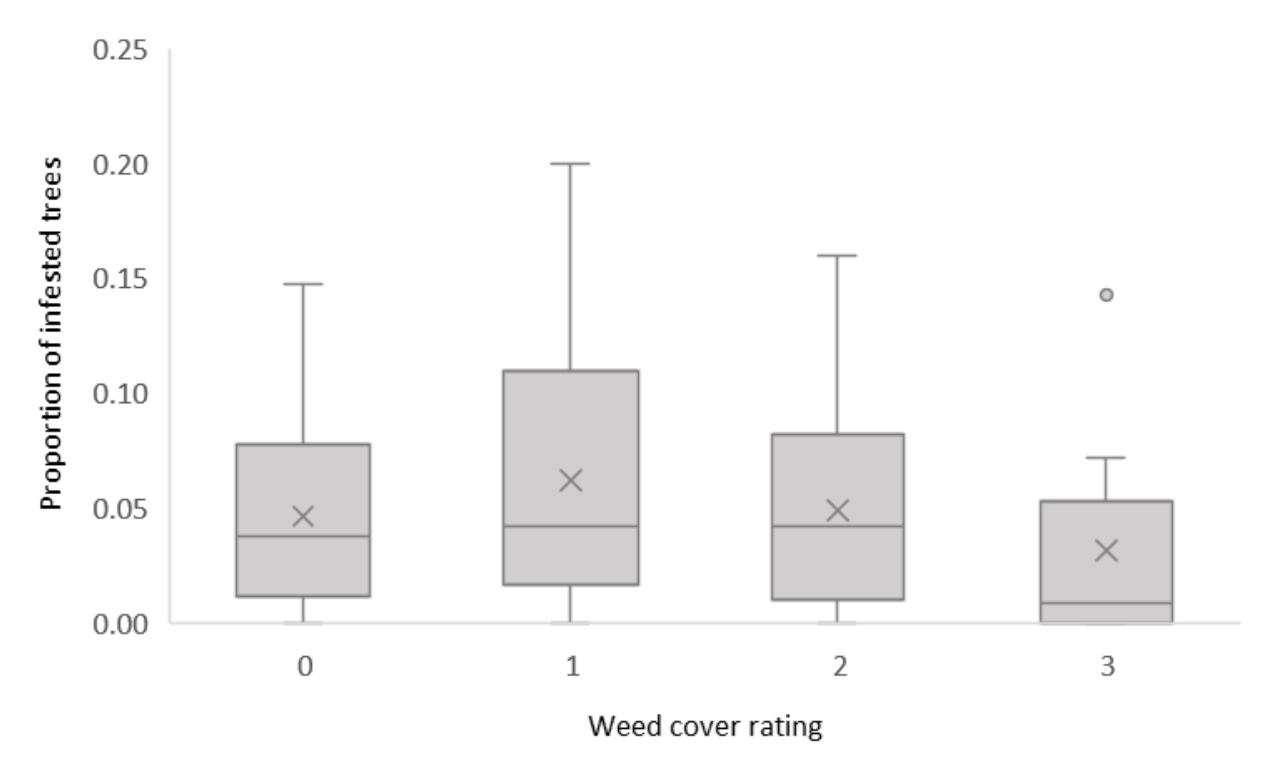

Figure 1. Mean proportion of peach trees in each weed coverage category infested with peachtree borer larvae.

\section{Discussion}

This study provides data that suggests orchard floor weed cover within tree rows does not influence the occurrence of peachtree borer infestation. Previous research has suggested that predator and parasitoid populations are likely to be more abundant and provide greater pest suppression in habitats with greater plant diversity compared to monocultures of plants [7,8]. Although a survey of natural enemies in the orchard floor was beyond the scope of this study, we did not observe a significant decrease in peachtree borer infestation as weed cover ratings increased. Similarly weed cover did not appear to physically impede the ability of peachtree borer to infest trees.

Our study provided a real-world environment to investigate the interactions of orchard floor weed cover on peachtree borer infestation. The two commonly adopted peachtree borer management tactics include mating disruption or a postharvest application of chlorpyrifos insecticide. Comparisons with untreated control blocks would have been ideal. However, the damage potential of peachtree borer would have made the inclusion of unmanaged blocks impossible in a commercial orchard. Even with management efforts in place, sufficient numbers of infested trees were available for study.

\section{Conclusion}

Although additional studies will be needed to understand how best to manage peachtree borer and perennial weeds in orchards, this research shows that management efforts for each are not likely to be counterproductive within the wholistic creation of an integrated orchard pest management program.

Author Contributions: Conceptualization, D.L.F. and R.S.C.; methodology, D.L.F. and R.S.C.; formal analysis, D.L.F.; investigation, D.L.F. and R.S.C.; data curation, D.L.F.; writing-original draft preparation, D.L.F.; writing - review and editing, D.L.F. and R.S.C; project administration, D.L.F. and R.S.C.; funding acquisition, D.L.F. and R.S.C. All authors have read and agreed to the published version of the manuscript.

Funding: This research was funded in part by USDA-NIFA EIPM, grant number 2014-70006-22578.

Informed Consent Statement: Not applicable. 
Acknowledgments: The authors thank Shanholtz Orchards for allowing the use of their orchard in this study.

Conflicts of Interest: The authors declare no conflict of interest.

\section{References}

1. Pfeiffer, D.G. (ed.) Spray Bulletin for Commercial Tree Fruit Growers, 2021. Publ. 456-419; Virginia, West Virginia, and Maryland Cooperative Extension; Virginia Polytechnic Institute and State University: Blacksburg, VA, USA, 2021; 180 p.

2. Altieri, M.A.; van Schoonhoven, A.; Doll, J. The ecological role of weeds in insect pest management systems: A review illustrated by bean (Phaselou vulgaris) cropping systems. PANS. 1977, 23, 195-205.

3. Andow, D.A. Vegetational diversity and arthropod population response. Annu. Rev. Entomol. 1991, 36, 561-586.

4. Norris, R.F.; Kogan, M. Ecology of interactions between weeds and arthropods. Annu. Rev. Entomol. 2005, 50, 479-503.

5. Akotsen-Mensah, C.; Boozer, R.T.; Fadamiro, H.Y. Influence of orchard weed management practices on soil dwelling stages of plum curculio, Conotrachelus nenuphar (Coleoptera: Curculionidae). Fla. Entomol. 2012, 95, 882-889.

6. Frank, D.L.; Starcher, S; Chandran, R.S. Comparison of mating disruption and insecticide application for control of peachtree borer and lesser peachtree borer (Lepidoptera:Sesiidae) in peach. Insects. 2020, 11, 658.

7. Snyder, W.E. Give predators a complement: Conserving natural enemy biodiversity to improve biocontrol. Biol. Cont. 2019, 135, 73-82.

8. Root, R.B. Organization of a plant-arthropod association in simple and diverse habitats: The fauna of collards (Brassica oleracea). Ecol. Monogr. 1973, 43, 95-124. 